\title{
Molecular identification of infectious bronchitis virus isolated from respiratory diseases in some Iranian broiler flocks
}

\author{
Mohsen Ghorbiani ${ }^{1} \cdot$ Zahra Boroomand $^{1} \cdot$ Mansour Mayahi $^{1} \cdot$ Masoud Reza Seyfi Abad Shapouri ${ }^{2}$
}

Received: 6 June 2020 / Accepted: 28 August 2020 / Published online: 5 September 2020

(c) Springer Nature B.V. 2020

\begin{abstract}
Infectious Bronchitis (IB) is an acute, highly contagious disease associated with respiratory signs in young chickens and reduced egg production and quality in layers. The purpose of this study was to isolate and identify the infectious bronchitis virus in broiler flocks with respiratory diseases in four provinces of Iran. The specimens from forty IB suspected flocks from different regions of Isfahan, East Azerbaijan, Golestan, and Khuzestan provinces were collected, and the trachea, lung, and cecal tonsils were sampled. The samples were inoculated into 9- to 11-day-old embryonated chicken eggs. After collecting the allantoic fluid, RT-PCR was carried out to detect IB viruses. The results showed that IBVs were isolated from $30 \%$ of the flocks in these four provinces. The positive samples, according to a partial S1 gene sequence, were more investigated. Comparing nucleotide and amino acid sequences showed that the four isolates had the most similarity to the Pakistani 793/B strain (GI-13 lineage). The three isolates had the most considerable similarity in amino acid and nucleotide sequences to Iraqi and Iranian QX-like viruses (GI-19 lineage). Two isolates had 96 to $98 \%$ resemblance to Iranian variant-2 (GI-23 lineage) isolates. One isolate was found to belong to the Massachusetts serotype (GI-1 lineage) having 100\% similarity in its amino acid sequence to the Massachusetts serotypes in GenBank. The phylogenetic relationship of the isolates shows complexity and diversity concerning different sequences and geographical regions.
\end{abstract}

Keywords Infectious bronchitis $\cdot$ Identification $\cdot$ Broiler flocks $\cdot$ Iran

\section{Introduction}

Infectious bronchitis is considered one of the most common diseases of poultry. This disease often affects both vaccinated and unvaccinated flocks and caused significant economic losses in Iranian flocks in the last years [1]. The infectious bronchitis virus (IBV) belongs to group III of the genus Coronavirus of the family Coronaviridae, has a positive- sense, single-stranded RNA coding for four structural proteins: the spike glycoprotein (S), the membrane glycoprotein $(\mathrm{M})$, the small envelope protein $(\mathrm{E})$, and the nucleocapsid protein $(\mathrm{N})$. The spike $(\mathrm{S})$ Protein forms the main structure of the IBV proteins is located on the surface of the

Zahra Boroomand

z.boroomand@scu.ac.ir

1 Department of Clinical Sciences, Faculty of Veterinary Medicine, Shahid Chamran University of Ahvaz, Ahvaz, Iran

2 Department of Pathobiology, Faculty of Veterinary Medicine, Shahid Chamran University of Ahvaz, Ahvaz, Iran viral envelope. This protein is the main factor in inducing the production of neutralizing antibodies, and is responsible for binding and entering the host cells. The $\mathrm{S}$ protein is broken down into two subunits, S1 and S2. It is observed that infectious bronchitis virus serotypes are 20 to $25 \%$ genetically different. This genomic and amino acid difference is higher in the S1subunit. The S1 diversity probably results from mutation, insertions, deletions, or RNA recombination of S1 genes [2]. Such diversity may lead to critical biological differences between strains, and new types of serotypes could appear due to partial amino acid changes in the S1 protein. Nucleotide heterogeneity is more present in the $\mathrm{S} 1$ portion of the $\mathrm{S}$ gene and contains mainly three different hypervariable regions (HVRs) (aa 38-67, 91-141, and 274-387) [3, 4]. In consequence, the complete or partial nucleotide sequence analysis of the $\mathrm{S} 1$ gene has been routinely used to verify viral genetic variants. Now, more than 50 different types of antigens and genetics of IBV are documented. Some of these viruses have a significant economic impact on the poultry industry, and others are limited to specific geographical areas [5, 6]. The two current sequence 
regions responsible for the encoding sequence HVRs 1 and two is located between nucleotides 112 and 423, and HVR3 between 820 and 1161 [7]. The first isolation of IBV from Iranian flocks was reported in 1994 [1]. After that, several Iranian researchers identified 793/B serotype [8]. The genotype of infectious bronchitis virus strains isolated from Iran during 2014-2015 was divided into seven phylogenetically different groups: Massachusetts (Mass), 793/B, IS- 1494, IS-720, QX, IR-1 and IR-2 [9]. At present, vaccination strategies to control infectious bronchitis in Iran's flocks are based on the Massachusetts and 4/91 serotypes $[8,10]$. However, due to the low cross-immunity between field and vaccine strain and continuously emerging new variants, there have been continuous reports of IB suspected cases in the whole country, because protection attained by vaccination has not been enough [11].

This study was conducted to isolate and identify the infectious bronchitis virus in broiler chicken flocks with respiratory symptoms from four provinces of Iran. Genotyping the national strains of infectious bronchitis is essential for the development and application of vaccination strategies. Determine antigenic characteristics of infectious bronchitis virus isolates is essential for choosing impressive new vaccines for geographically related regions.

\section{Materials and methods}

\section{Sampling}

Of forty flocks with respiratory symptoms, from 2018 to 2019 from Golestan, Khuzestan (Table 1), Isfahan, and East Azerbaijan (Table 2) provinces of Iran, after recording the history of each flock (the flock ages and vaccination programs), samples were taken from trachea, lung, and cecal tonsils tissues of ten dead birds of each flock. The autopsy of dead chicks showed a wide range of symptoms, from asymptomatic to exudate in the trachea, foamy air sac, swelling of the kidneys, casts in trachea bifurcation, and pneumonia. The samples were transported, on dry ice, to the laboratory of Faculty of Veterinary Medicine, Ahvaz, being kept at $-70{ }^{\circ} \mathrm{C}$ until testing.

\section{Virus isolation}

The tissue samples were separately crushed and added to phosphate-buffered saline (PBS) containing penicillin $10000 \mathrm{IU} / \mathrm{ml}$, streptomycin 10,000 $\mu \mathrm{g} / \mathrm{ml}$, and amphotericin B250 $\mu \mathrm{g} / \mathrm{ml}$ then, the homogeneous tissue mixtures were centrifuged at $1000 \mathrm{rpm}$ for $10 \mathrm{~min}$. the supernatants were used as inoculums [12]. $0.2 \mathrm{ml}$ of each sample was
Table 1 The broiler chicken farm history of Golestan (rows one to ten), and Khuzestan (rows 11 to 20) provinces of Iran and their molecular results

\begin{tabular}{|c|c|c|c|c|c|c|c|c|}
\hline \multirow{2}{*}{$\begin{array}{l}\text { Broiler } \\
\text { flocks } \\
\text { number }\end{array}$} & \multirow{2}{*}{$\begin{array}{l}\text { Age of } \\
\text { broiler flocks } \\
\text { (day) }\end{array}$} & \multicolumn{3}{|c|}{$\begin{array}{l}\text { Vaccine program (method and age } \\
\text { by day number) }\end{array}$} & \multicolumn{3}{|c|}{$\begin{array}{l}\text { RT-PCR results (posi- } \\
\text { tive sample) }\end{array}$} & \multirow[t]{2}{*}{$\begin{array}{l}\text { Isolated } \\
\text { genotype }\end{array}$} \\
\hline & & H120 & Ma5 & $4 / 91$ & Trachea & Lung & $\begin{array}{l}\text { Cecal } \\
\text { Toncil }\end{array}$ & \\
\hline 1 & 9 & 1-Spray & 9-Drinking & 17 Drinking & - & - & - & - \\
\hline 2 & 10 & 4-Spray & - & - & - & - & $8 / 10$ & GI-19 lineage \\
\hline 3 & 12 & 2-Spray & 7-Drinking & 18-Drinking & - & - & - & - \\
\hline 4 & 35 & 1-Spray & 8 Drinking & 17-Drinking & - & - & - & - \\
\hline 5 & 41 & - & - & 16-Drinking & - & - & - & - \\
\hline 6 & 21 & 3-Spray & - & - & $6 / 10$ & - & $5 / 10$ & GI-19 lineage \\
\hline 7 & 27 & 3-Spray & 8 Drinking & - & - & - & $9 / 10$ & GI-19 lineage \\
\hline 8 & 24 & 2-Spray & 8 Drinking & - & - & - & - & - \\
\hline 9 & 38 & 1-Spray & - & - & - & - & - & - \\
\hline 10 & 13 & 1-Spray & - & - & - & - & - & - \\
\hline 11 & 39 & 1-Spray & 7-Drinking & 18 Drinking & - & - & - & - \\
\hline 12 & 42 & 3-Spray & 8 Drinking & - & - & - & - & - \\
\hline 13 & 37 & 1-Spray & 7 Drinking & 16-Drinking & - & - & - & - \\
\hline 14 & 29 & 1-Spray & 8-Drinking & - & - & - & - & - \\
\hline 15 & 14 & 1-Spray & - & - & - & $3 / 10$ & $9 / 10$ & GI-23 lineage \\
\hline 16 & 34 & 1-Spray & - & - & - & - & - & - \\
\hline 17 & 31 & 1-Spray & 8-Drinking & 18-Drinking & - & - & - & - \\
\hline 18 & 24 & 1-Spray & 8-Drinking & 16-Drinking & - & - & - & - \\
\hline 19 & 20 & 1-Spray & 8-Drinking & - & - & - & - & - \\
\hline 20 & 37 & 1-Spray & 8-Drinking & - & - & - & - & - \\
\hline
\end{tabular}


Table 2 The broiler chicken farm history of Isfahan (rows one to ten), and East Azerbaijan (rows 11 to 20) provinces of Iran and their molecular results

\begin{tabular}{|c|c|c|c|c|c|c|c|c|}
\hline \multirow[t]{2}{*}{$\begin{array}{l}\text { Broilerflocks } \\
\text { number }\end{array}$} & \multirow[t]{2}{*}{$\begin{array}{l}\text { Age of broiler } \\
\text { flocks (day) }\end{array}$} & \multicolumn{3}{|c|}{$\begin{array}{l}\text { Vaccine program (method and age by day } \\
\text { number) }\end{array}$} & \multicolumn{3}{|c|}{ RT-PCR results (positive sample) } & \multirow[t]{2}{*}{$\begin{array}{l}\text { Isolated } \\
\text { Genotype }\end{array}$} \\
\hline & & H120 & Ma5 & $4 / 91$ & Trachea & Lung & $\begin{array}{l}\text { Cecal } \\
\text { Toncil }\end{array}$ & \\
\hline 1 & 40 & 1-4Spray & 9-Drinking & 16-Drinking & - & - & - & - \\
\hline 2 & 7 & 3-Spray & - & - & - & - & $5 / 10$ & GI-1 lineage \\
\hline 3 & 13 & 1-Spray & - & - & $7 / 10$ & $5 / 10$ & - & Sequencing failed \\
\hline 4 & 39 & - & 6-Drinking & 17-Drinking & - & - & - & - \\
\hline 5 & 25 & 2-Spray & 9-Drinking & - & - & - & - & - \\
\hline 6 & 17 & 1-Spray & 8-Drinking & - & - & - & - & - \\
\hline 7 & 24 & - & - & - & - & - & $7 / 10$ & GI-13 lineage \\
\hline 8 & 28 & 1-Spray & - & - & - & - & $5 / 10$ & GI-13 lineage \\
\hline 9 & 16 & 2-Spray & 8-Drinking & - & - & - & - & - \\
\hline 10 & 9 & - & - & - & - & - & - & - \\
\hline 11 & 40 & 1-Spray & & 7-Drinking & - & - & - & - \\
\hline 12 & 19 & 1-Spray & 8-Drinking & - & - & - & $5 / 10$ & GI-13 lineage \\
\hline 13 & 33 & 1-Spray & 7-Drinking & 16-Drinking & - & - & - & - \\
\hline 14 & 28 & 1-Spray & 8-Drinking & 18-Drinking & - & - & - & - \\
\hline 15 & 12 & 1-Spray & - & - & - & - & - & - \\
\hline 16 & 24 & 1-Spray & 6-Drinking & - & - & - & $9 / 10$ & Sequencing failed \\
\hline 17 & 37 & 1-Spray & 6-Drinking & 18-Drinking & - & - & - & - \\
\hline 18 & 8 & - & - & - & $6 / 10$ & - & $9 / 10$ & GI-23 lineage \\
\hline 19 & 20 & 1-Spray & 10-Drinking & 18-Drinking & - & - & $7 / 10$ & GI-13 lineage \\
\hline 20 & 39 & 1-Spray & 8-Drinking & - & - & - & - & - \\
\hline
\end{tabular}

inoculated into allantoic cavities of five 9-day-old embryonated chicken eggs. The eggs were incubated at $37^{\circ} \mathrm{C}$ for 48-72 h. The allantoic fluid was harvested. RT-PCR test was conducted, and negative cases were serially passaged up to three times.

\section{RNA extraction}

$1000 \mu \mathrm{l}$ of RNX solution (CinnaGen, Iran) was added to $200 \mu \mathrm{l}$ of the allantoic fluid; RNA was extracted according to the manufacturer's guide form and kept at $-80{ }^{\circ} \mathrm{C}$ until cDNA synthesis.

\section{cDNA synthesis}

For the cDNA synthesis, random primer and cDNA Synthesis Kit (YektaTajhizAzma, Iran) were used. The synthesized cDNA was stored at $-20^{\circ} \mathrm{C}$.

\section{PCR reaction}

To conduct the process, a pair of infectious bronchitis S1-specific primers XCE1 (5'-CACTGGTAATTTTTC AGATGG-3) and XCE2 (5'-CTCTATAAACACCCTTAC
A-3') were used [13]. The components were mixed at the following concentrations: $10 \mu l$ of $1.5 \mathrm{mM} 2 \mathrm{X}$ Master Mix, $\mathrm{MgCl} 2$, (Ampliqon, Canada), primer XCE1 $(10 \mathrm{pM} / \mu l)$, primer XCE2 $(10 \mathrm{pM} / \mu l), 3 \mu l$ of template DNA and, $6 \mu l$ of water in the final volume of $20 \mu l$ using thermocycler at $94{ }^{\circ} \mathrm{C}$ for $5 \mathrm{~min}$ (early Denaturation), 35 cycles $30 \mathrm{~s}$ at $94{ }^{\circ} \mathrm{C}$ (Denaturation); $30 \mathrm{~s}$ at $55^{\circ} \mathrm{C}$ (Annealing), and $35 \mathrm{~s}$ at $72^{\circ} \mathrm{C}$ (Extension). Subsequently, Final Elongation was performed at $72{ }^{\circ} \mathrm{C}$ for $4 \mathrm{~min}$. It should be noted that during all steps of PCR reaction, a negative control (distilled water instead of DNA) and positive control (RNA extracted from Mass-type H120 and 4/91 vaccines) were included.

\section{Evaluation of PCR products}

The PCR products were electrophoresed in $1 \%$ agarose gel at $100 \mathrm{~V}$ and after safe-staining were visualized under UV light. 100 bp DNA marker (CinnaGen, Iran) was used. Fifty $\mu l$ of positive PCR products with $10 \mu l$ of both XCE1 and XCE2 primers were sent to Takapouzist Company, Iran, for purification and sent to BIONEER, South Korea, for sequencing. 


\section{Results}

In the molecular investigation, twelve flocks were IBVpositive. Overall, 106 of 1200 samples were positive in the RT-PCR test, and the results in each province are as the following:

Golestan: 28 positive cases of 3 flocks, Khuzestan: 12 positive cases of one flock, Isfahan: 31 positive cases of 4 flocks, and East Azerbaijan: 35 positive cases of 4 flocks (Table 1). The PCR product size was 464 base pairs that polymerized the hypervariable region 3 (HVR3) between nucleotide positions 671 and 1135 of theS 1 gene sequence.

One positive sample of each flock was sequenced by the BIONEER Company, and the Blast program at the NCBI was used for the obtained sequence. Also, the sequences were compared with the other serotypes identified in Iran, the neighboring countries, and the world; the percentage of nucleotide and amino acid sequence similarity was calculated.

Obtained sequences were submitted to GenBank and given an accession number; IBV-80 (MK850432), IBV-29 (MK850425),IBV-83 (MK850428), IBV-56 (MK850431), IBV-17 (MK850424), IBV-16 (MK850430), IBV-8 (MK850423),IBV-106 (MK850429),IBV-34 (MK850426), IBV-35 (MK850427). A phylogenetic tree was drawn, based on genes and amino acid sequences obtained from GenBank containing serotypes and strains of infectious bronchitis virus and sequences obtained from this study using

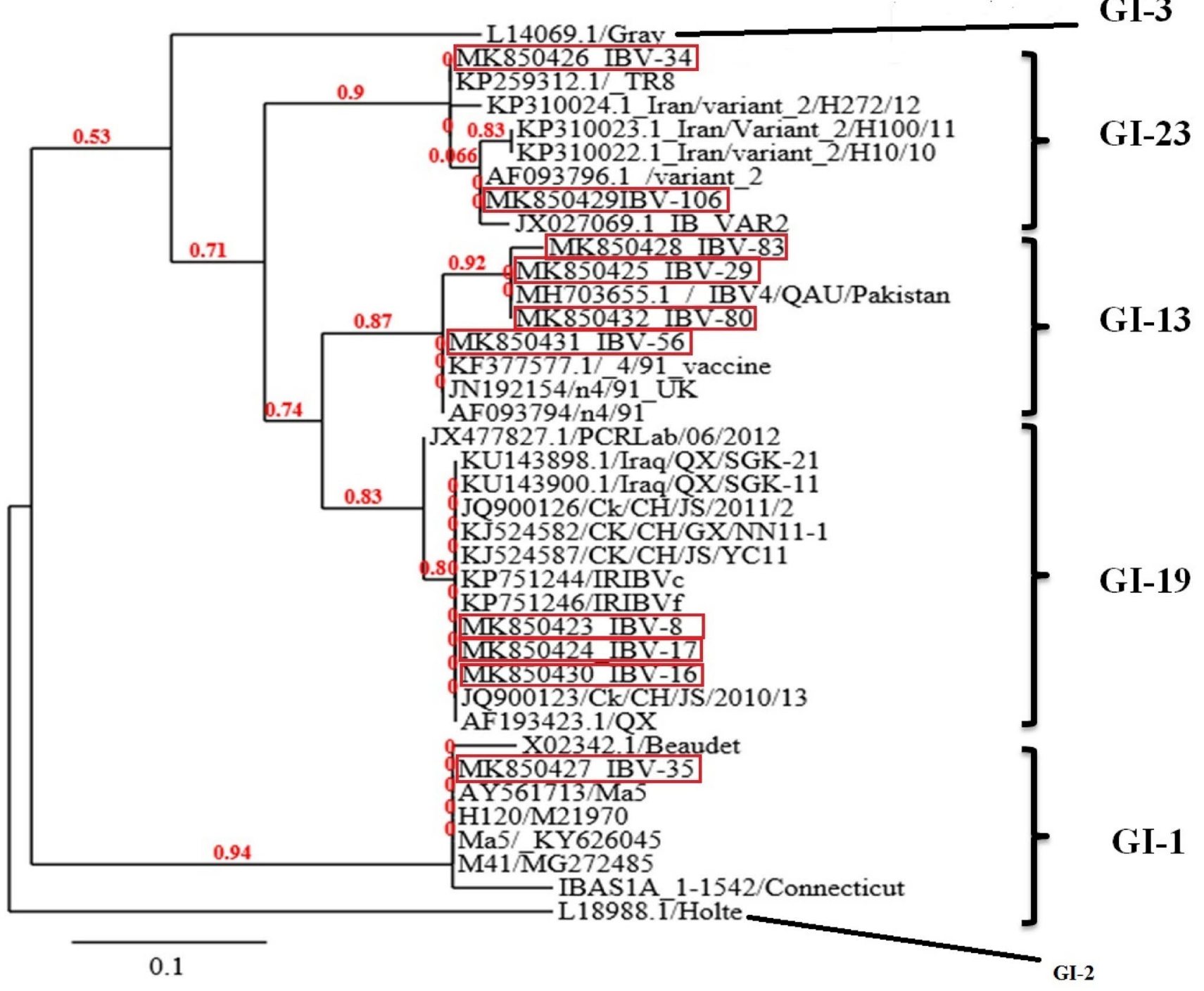

Fig. 1 The phylogenetic tree based on the partial S1 gene (HVR3) nucleotide sequence of isolates obtained from this study, marked with a red line, and 36 IBVs isolated from poultry. The distance between the branches indicates similarity/dissimilarity 
the program https://www.phylogeny.fr/simple-phylogeny. cgi (Figs. 1 and 2).

The results of comparing the nucleotide sequence revealed that all isolates of this research were in genotype I. The four isolates MK850428 (IBV-83), MK850425 (IBV-29), MK850432 (IBV-80), and MK850431 (IBV-56) had 98.56 to $99.59 \%$ similarity to the Pakistani strain of GI-13 lineage (4/91serotype). The isolate MK850431 (IBV-56) was similar to the vaccine strain of GI-13 lineage (4/91serotype). The three isolates MK850432 (IBV-8), MK850430 (IBV-16), and MK850424 (IBV-17) were placed in GI-19 lineage (QX-like viruses) having 98 to over $99 \%$ similarity to the Iraqi and Iranian QXlike viruses. The two isolates MK850426 (IBV-34), and
MK850429 (IBV-106) are placed in GI-23 lineage (variant-2), having 95 to $97 \%$ similarity to the previously isolated Iranian strains of GI-23 lineage. Comparing amino acid sequence showed that four isolates belonging to GI-13 lineage (793/B serotype) in the research had more similarity to the Pakistani strain. Three isolates belonging to GI-19 lineage (QX-like viruses) had more similarity in amino acid sequence to the Iraqi QX viruses. 2 isolates belonging to GI-23 lineage (variant-2) had 96 to $98 \%$ similarity to the Iranian isolates. Having a $100 \%$ similarity in amino acid sequence to the GI-1 lineage (Massachusetts serotype) existing in GenBank, the isolate MK850427 (IBV-35) in this research belongs to the Massachusetts serotype.

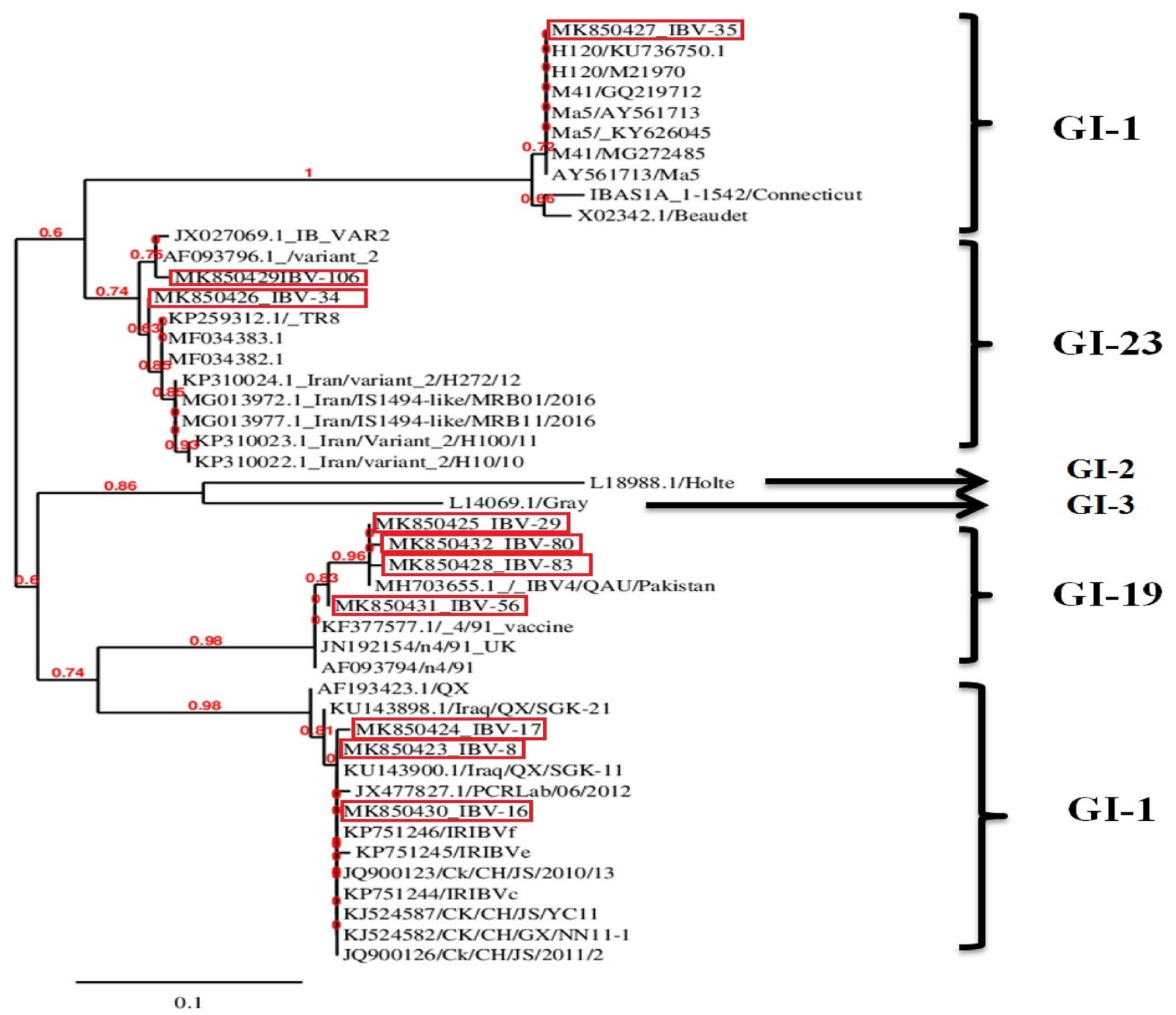

Fig. 2 The phylogenetic tree based on the partial S1 amino acid sequence of IBVs obtained from this study, marked with a red line, and 36 IBVs isolated from poultry. The distance between the branches indicates similarity/dissimilarity 


\section{Discussion}

Unfortunately, weakness of management and structure in many of the Iranian poultry flocks and The high replication rate of this virus, mutation by deletion or insertion of RNA fragments and recombination, result in recombinants, variants and new, re-emerging strains of infectious bronchitis virus [9, 14]. Many genetic changes occur in the infectious bronchitis virus is caused by both recombination and mutations, for example, replacement, deletion, and insertion, which can lead to the appearance of new variants. The factors that generate the right conditions for such events are the large single-stranded RNA in the genomic structure of the coronaviruses, virus biology (Minutest proofreading activity of the viral polymerase), modern poultry breeding behaviors and immunological stress resulting from use vaccines [15]. The $S 1$ gene mutations cause new genotypes or serotypes [5]. The virus number, variety, naming, and the multiplicity of methods used to verify them over the years, have generated considerable fuss. To prevent this, new classification based on the phylogeny of the S1 gene and new naming has been planned. This system differentiated 32 lineages and collected in 6 genotypes (GI to GVI), the GI genotype contained GI-1 to 27 lineages [7]. However, in recent years, two more lineage (GI-28 and 29) and even another genotype (GVII) have been recognized in China [15]. Due to their wide geological circulation, some lineages are more important. Between these, GI-1 and -13 (Mass and 793B, respectively) are frequently found, resulting in the vaccines derived from them in the countries reported. Contrary, other lineages are limited to certain regions [7].

In the present study, IBV was isolated from $30 \%$ of the 40 flocks from different regions of Iran. 793/B serotype (GI-13 lineage) was predominant, followed by QX-like (GI-19 lineage), variant-2 (GI-23 lineage), and the Massachusetts (GI-1 lineage) isolates, respectively. Overall, the four lineages were circulating in the 40 flocks. Since 1998, serotypes 793/B (GI-13 lineage) and Massachusetts (GI-1 lineage) have been the most common viruses in the Iranian farms $[14,16,17]$. However, there may have been other variants that probably have not been identified. Modiri et al. [16] also attempted to genotype IBV circulating in the Iranian broiler flocks from 2015 to 2017 showed that $52.16 \%$ of the flocks were IBV-positive. These researchers reported variant -2 (IS-1494-like viruses) as the predominant type, followed by 793/B, Massachusetts, and QX-like viruses, respectively. They said that IR-1, IS-720, and IR-2 IB had disappeared, based on the latest research (2014-2015) and other reports from Iran [18]. Ghahremani et al. [19] carried out a phylogenetic study on ten isolates of infectious bronchitis, isolated from 1998 to
2008 from trachea and lung samples of broiler with clinical signs suggestive of infection bronchitis. Their results showed that three isolates belonged to the Massachusetts serotype (GI-1 lineage), and seven isolates belonged to the 4/91 serotype (GI-13 lineage). Four isolates were identified and phylogenetically studied in this study located in the 793/B serotype (GI-13 lineage). All the four obtained isolates in this study had over $99 \%$ similarity to the Pakistani isolate [19]. 793/B serotype was isolated from Britain in 1991 for the first time [20]. Later on, this serotype spread in most parts of Europe, Asia, and North America, until it became the most common serotype of the countries of these regions. To investigate the prevalence of the infectious bronchitis virus in Iran, Seyfi et al. [13] took swabs from 77 broiler flocks in 16 provinces of Iran. The results showed a relatively high prevalence $(42.8 \%)$ of 793/B strain of IBV in Iran. The GI-13 lineage (793B, also known as 4/91 and CR88) is present in many parts of the world, both vaccine and virulent field strains [7].

The second identified viruses in this study were similar in the partial S1 gene (HVR3) to the GI-19 lineage (QX-like viruses). For the first time, a disease associated with gastritis, diarrhea, and weight loss in 25 to 75 days old chickens was reported from China in 1996. The disease was named infectious bronchitis, and its strain was identified as QX. However, the isolate was not recognized as a new variant of IBV at that time. From 1999 to 2004, five flocks from four provinces of China were investigated, and the results showed that QX-like viruses were a new nephropathogenic strain [21]. Recent studies show that the QX-like viruses (GI-19lineage), circulate in many European and Asian countries. After that, QX became one of the most common IBV genotypes in different countries [18]. QX-like IBVs spread from China to Europe and Southern Africa [22]. In Iran, Bozorgmehri et al. [23], isolated a QX-like virus (GI-19 lineage) for the first time, they found that the prevalence of the virus during 2010-2014 and 2014-2015 was 9.6\% and $10 \%$, respectively. Boroomand et al. [11] carried out a phylogenetic analysis of infectious bronchitis viruses isolated from broiler flocks of Khuzestan province, Southwest Iran, and classified them into QX-like viruses (GI-19lineage). Due to considerable similarity of the three isolates to the Iraqi QX-like strains and because Iraq is a neighboring country bordering Khuzestan, it was presumed that the viruses have spread from Iraq to this province [11]. The present study shows a low frequency of GI-19lineage in Khuzestan province, probably due to the combined effect of the Massachusetts and 793/B vaccine.

Epidemiological studies on the analysis of IBV in Italy and Spain showed that using a combined vaccine (Massachusetts and 793/B) decreased the outbreak of the QX like viruses [24]. Two other isolates of the virus were identified in the present study belong to GI-23 lineage (variant -2), 
and strains of this serotype, in turn, belong to the field isolates. The GI-23 lineage (variant 2) is geographically limited to The Middle East. Some dominate most farms and are involved in respiratory and kidney diseases [7]. The Egypt/Beni-Suef/01 IBV with $99 \%$ similarity to the GI-23 lineage had been isolated from Egypt in 2001 [25]. Since then, IS-1494-like IBV has been tracked in Jordan, Turkey, and other countries of the Middle East [24]. In Iran, a GI-23 lineage (variant 2) was identified in 2010 for the first time, and then, it was reported as the second country among the eight countries with the most common variant 2 incidences between 2014 and 2015. After that, Najafi et al. [9] in their molecular researches reported the variant-2 as the predominant IBV during 2014-2015. Varinat 2 viruses are still among the main strains of Jordan, Egypt, Turkey,and other countries of the Middle East [9]. Because variant 2 vaccine is not used in Iran and the current vaccines do not confer complete protection against this virus, the possibility of a wider spread of this variant is high [26].

The fourth virus identified in this study is identical in gene sequence to vaccine strain of the Massachusetts serotype (GI-1 lineage), and therefore, this isolate belongs to the GI-1 lineage. According to field history, chickens were vaccinated with H120 strain at 3 days of age, and sampling was performed on day seven. Therefore, it may be the same vaccine strain. The widely distributed GI-1 lineage (Massachusetts serotype) includes the first known IBV serotype, possibly due to the widespread use of a homologous vaccine derived from one of its strains. This lineage includes mainly associated with respiratory disease [7]

Overall, in this study, the most prevalent IBV genotypes in some regions of Iran, are GI-13, GI-19, and GI-23 lineages. This study helps us survey the circulating strains of IBV to see if a new type emerged to develop our national vaccination efficiency in broiler chicken. Furthermore, it is necessary to produce a vaccine to control the increasing spread of variant-2.

Funding The authors would like to express their thankfulness to the Vice-Chancellor for Research of the ShahidChamran University of Ahvaz for providing financial support for this work.

\section{Compliance with ethical standards}

Conflict of interest The authors declare that they have no conflict of interest.

Research involving human and animal participants This article does not contain any studies involving animals or human participants performed by any of the authors.

\section{References}

1. Aghakhan SM, Abshar N, Fereidouni SR, Marunesi C, Khodashenas M (1994) Studies on avian viral infection in Iran. Arch Razi Inst 44(45):1-10

2. Jackwood MW, de Wit S (2013) Infectious bronchitis. In: Swayne DE, Glisson JR, McDougald LR, Nolan LK, Suarez DL, Nair V (eds) Diseases of Poultry, 13th edn. Blackwell Publishing, Ames, pp 139-159

3. Cavanagh D, Davis PJ, Mockett AA (1988) Amino acidswithin hypervariable region 1 of avian coronavirus IBV (Massachusetts serotype) spike glycoprotein are associated with neutralization epitopes. Virus Res 11(2):141-150

4. Moore KM, Jackwood MW, Hilt DA (1997) Identification of amino acids involved in a serotype and neutralization specific epitope within the s1 subunit of avian infectious bronchitis virus. Arch Virol 142(11):2249-2256

5. De Wit JJ, Cook JK, Van der Heijden HM (2011) Infectious bronchitis virus variants: a review of the history, current situation and control measures. Avian Pathol 40(3):223-235

6. Jackwood MW (2012) Review of infectious bronchitis virus around the world. Avian Dis 56(4):634-641

7. Valastro V, Holmes EC, Britton P, Fusaro A, Jackwood MW, Cattoli G, Monne I (2016) S1 gene-based phylogeny of infectious bronchitis virus: an attempt toharmonize virus classificationInfection. Genet Evol 39:349-364

8. Seyfi Abad Shapouri MR, Mayahi M, Assasi K, Charkhkar S (2004) A survey of the prevalence of infectious bronchitis virus type 4/91 in Iran. Acta Vet Hung 52:163-166

9. Najafi H, Langeroudi AG, Hashemzadeh M, Karimi V, Madadgar O, Ghafouri SA, Maghsoudlo H, Farahani RK (2016) Molecular characterization of infectious bronchitis viruses isolated from broiler chicken farms in Iran, 2014-2015. Arch Virol 161:53-62

10. Hashemzadeh M, Karimi V, Masoudi S, Shoushtary AH, Langeroudi AG, Momayez R, Shirazi MN, Maghsodloo H, Hasanzadeh R, Eshratabadi F (2013) Phylogenetic study of Iranian infectious bronchitis virus isolates during using glycoprotein S1 gene. J Vet Res 68:135-141

11. Boroomand Z, Jafari RA, Mayahi M (2018) Molecular detection and phylogenetic properties of isolated infectious bronchitis viruses from broilers in Ahvaz, southwest Iran, based on partial sequences of spike gene. Vet Res Forum 9:279-283

12. Williams SM, Dufour-Zavala L, Jackwood MW, Lee MD, Lupiani B, Reed WM, Spackman E, Peter R, Woolcock PR (2016) A laboratory manual for the isolation and identification of avian pathogens, 6th edn. American Association of Avian Pathologists, College Station, pp 169-174

13. Adzhar A, Gough RE, Haydon D, Shaw K, Britton P, Cavanagh D (1997) Molecular analysis of the 793/B serotype of infectious bronchitis virus in Great Britain. Avian Pathol 26:625-640

14. Hosseini H, Fard MH, Charkhkar S, Morshed R (2015) Epidemiology of Avian infectious bronchitis virus genotypes in Iran 2010-2014. Avian Dis 59:431-435

15. Blicharz KD, Lisowska A, Krukowska JS (2020) Molecular epidemiology of infectious bronchitis virus in Poland from 1980 to 2017. Infect Genet Evol 80:104177

16. Hamadan AM, Ghalyanchilangeroudi A, Hashemzadeh M, Hosseini H, Karimi V, Yahyaraeyat R, Najafi H (2017) Genotyping of Avian infectious bronchitis viruses in Iran (20152017) reveals domination of IS-1494 like virus. Virus Res 240:101-106

17. Nouri A, Assasi K, Seyfi Abad Shapouri MR (2003) Field study of infectious bronchitisvirus using type specific RT-PCR. Arch Razi Inst 55:1-10 
18. Sasipreeyajan TPJ (2012) The pathogenesis of a new variant genotype and QX-like infectious bronchitis virus isolated from chickens in Thailand. Thai J Vet Med 42:51-57

19. Ghahremani N, Fard MB, Shoushtari H, Momayez R, Sheikhi N, Khoshzahmat A, Eshratabadi F (2011) Molecular analysis of infectious bronchitis virus isolated in Iran from 1998-2008. J Anim Vet Adv 10:2961-2967

20. Gough RE, Randall CJ, Dagless M, Alexander DJ, Cox WJ, Pearson D (1999) A "new" Strain of infectious bronchitis virus infecting domestic fowl in Great Britain. Vet Rec 130:493-494

21. Liu SW, Zhang QX, Chen JD, Han ZX, Liu X, Feng L, Shao YH, Rong JG, Kong XG, Tong GZ (2006) Genetic diversity of avian infectious bronchitis coronavirus strains isolated in chicken between 1999 and 2004. Arch Virol 151:1133-1148

22. Amin OG, Valastro V, Salviato A, Drago A, Cattoli G, Monne I (2018) Circulation of QX-like infectious bronchitis virus in the Middle East. Vet Rec 171:530

23. Bozorgmehri-Fard MH, Charkhkar S, Hosseini H (2014) Detection of the Chinese genotype of infectious bronchitis virus (QXtype) in Iran. Iran J Virol 7:21-24
24. Franzo G, Tucciarone CM, Blanco A, Nofrarías M, Biarnés M, Cortey M, Majó N, Catelli E, Cecchinato M (2016) Effect of different vaccination strategies on IBV QX population dynamics and clinical outbreaks. Vaccine 34:5670-5676

25. Gelb J Jr, Weisman Y, Ladman BS, Meir R (2005) S1 gene characteristics and efficacy of vaccination against infectious bronchitis virus field isolates from the United States and Israel (1996 to 2000). Avian Pathol 34:194-203

26. Habibi M, Karimi V, Langeroudi AG, Ghafouri SA, Hashemzadeh M, Farahani RK, Maghsoudloo H, Abdollahi H, Seifouri P (2017) Combination of $\mathrm{H} 120$ and 1/96 avian infectious bronchitis virus vaccine strains protect chickens against challenge with IS/1494/06 (variant 2)-like infectious bronchitis virus. Actavirol 61:150-160

Publisher's Note Springer Nature remains neutral with regard to jurisdictional claims in published maps and institutional affiliations. 